\title{
INHIBITORY ACTIVITY OF POTENTOX AGAINST DNA GYRASE OF ENTEROBACTERIACEAE
}

\author{
Manu Chaudhary and Anurag Payasi \\ Department of Cell Culture and Molecular Biology, \\ Venus Medicine Research Centre, Baddi, H.P, 173205, India
}

Received 2013-12-11; Revised 2013-12-12; Accepted 2014-02-08

\begin{abstract}
DNA gyrase, a type II topoisomerase catalyzes the supercoiling of relaxed closed circular DNA. In this report we evaluated the in vitro inhibitory effect of non antibiotic adjuvant compounds disodium edetate and sodium citrate against supercoiling activity of bacterial DNA gyrase. Further, we assessed the effect of different drugs alone and in combination with one or more adjuvants in overcoming FQ resistance. A total of twelve DNA gyrase mutant strains three of each Escherichia coli, Pseudomonas aeruginosa, Acinetobacter baumannii and Klebsiella pneumoniae were used in the study. MICs of drugs were determined by the agar dilution method following the Clinical and Laboratory Standards Institute (CLSI) guidelines. Potentox was the most active against all the selected mutants of with MIC values ranging 16-32 $\mu \mathrm{g} \mathrm{mL} \mathrm{L}^{-1}$. DNA gyrase showed optimum supercoiling activity at $60 \mathrm{mM} \mathrm{Mg}{ }^{2+}$. DNA gyrase inhibition was observed with low concentrations of disodium edetate and 50 and $100 \%$ inhibition on DNA gyrase activity was noted at approximately 4.2 and $10 \mathrm{mM}$ disodium edetate. On the other hand, 50 and $100 \%$ inhibition of DNA gyrase was found at 65 and $140 \mathrm{mM}$ sodium citrate. Furthermore, results revealed that Potentox inhibited the supercoiling activity of DNA gyrase at half of MIC of drug whereas other comparator drugs except gatifloxacin did not inhibit significantly the supercoiling activity of mutants as well as positive control. Potentox and gatifloxacin inhibited DNA gyrase and supercoiling at lower concentration and were the most effective. Although DNA gyrase from mutants was highly resistant to quinolones but sensitive to Potentox. Based on these results, it can be concluded that Potentox is an effective solution for the treatment of infections caused by fluoroquinolone resistant organism having DNA gyrase mutation.
\end{abstract}

Keywords: Antibiotic Adjuvant, Fluoroquinolones, DNA Gyrase

\section{INTRODUCTION}

The quinolones are a family of synthetic broadspectrum antibacterial drugs and majority of them are being implicated in clinical use belonging to the Fluoroquinolones (FQs), which have a fluorine atom at C-6 position or C-7 position (Sato et al., 2011). Quinolones are known to inhibit DNA synthesis by inhibiting the supercoiling activity of DNA gyrase ultimately inhibiting the growth of bacteria and killing them (Ruiz, 2003). DNA gyrase is considered as an essential enzyme for the DNA replication of chromosomes, plasmids and catalyzes the supercoiling of relaxed closed circular DNA (Hawkey, 2003; Morgan-Linnell et al., 2009). DNA gyrase is the only enzyme that negatively supercoils DNA in the presence of ATP (Tretter and Berger, 2012).

DNA gyrase from Escherichia coli is comprised of two sub units (GyrA and GyrB) with molecular weights 97 and $90 \mathrm{kDa}$, respectively (Tretter and Berger, 2012). Furthermore, they described that the A subunit is involved with interactions with DNA, it contains the active-site tyrosine responsible for DNA cleavage and the B subunit contains the ATPase active site. DNA gyrase (topoisomerase II) is the prime target of the FQs in gram-negative bacteria (Jacoby et al., 2006), Corresponding Author: Anurag Payasi, Department of Cell Culture and Molecular Biology, Venus Medicine Research Centre, Baddi, H.P, 173205 India, Tel: 91-1795-302068; Fax: 91-1795-302133 
contributing to the success of quinolones as antibacterial agents. Emergence of quinolone resistant pathogens has been observed in recent years which has imposed a major threat to the clinicians.

A plenty of studies revealed that FQ resistance mediated by alteration in the gene encoding DNA gyrase (topoisomerase II) among Enterobacteriaceae has increased largely in last decade (Morgan-Linnell et al., 2009; Jacoby et al., 2006). Mutations in GyrA (the gene for which gyrA encodes the A subunit of DNA gyrase) is the most common mechanism involved in quinolone resistance among gram-negative bacteria (Gruger et al., 2004). In addition to this, FQs resistance is also due to the expression of efflux pump (Coyne et al., 2011; Chaudhary and Payasi; 2012; Chaudhary et al., 2012), outer membrane protein alterations (Chenia et al., 2006) and plasmid mediated resistance (Strahilevitz et al., 2009).

The rising resistance and failure of existing therapy pushes for search of new compounds/methods with potent antibacterial activity against FQ resistance. Therefore, in the present study we evaluated the in vitro inhibitory effect of non antibiotic adjuvant compounds disodium edetate and sodium citrate against supercoiling activity of bacterial DNA gyrase. Further, we assessed the effect of different drugs alone and in combination with one or more adjuvants in overcoming FQ resistance.

\section{MATERIALS AND METHODS}

\subsection{Chemicals}

Poly(ethyleneimine) $(50 \%, \mathrm{w} / \mathrm{v})$ and spermidine were obtained from Sigma-Aldrich (USA). Adenosine-5triphosphoric acid disodium salt and ethidium bromide were from Spectrochem (Mumbai, India). Bovine serum albumin, magnisium chloride, agarose, ammonium sulfate, potassium chloride, sucrose, lysozyme, Soyabean Casein Digest Medium (SCDM), sodium chloride, ethylenediamine tetraacetic acid disodium (disodium edetate) and DL-dithiothreitol were purchased from HiMedia (Mumbai, India). Rexaled (pHOT-1) DNA was from TopoGEN (Florida, USA).

\subsection{Bacterial Strains}

A total of twelve DNA gyrase mutant strains three of each Escherichia coli, Pseudomonas aeruginosa, Acinetobacter baumannii and Klebsiella pneumoniae were kindly gifted by Dr. N.D Chaurasiya (National Centre for Natural Products Research, School of Pharmacy, University of Mississippi, USA). The identity of these isolates were reconfirmed using previously described methods (Khan et al., 2011). P. aeruginosa PAO strain MTCC 3541 was obtained from Institute of Microbial Technology (IMETCH), Chandigarh, India. All these isolates were grown in SCDM and harvested at $\log$ phase and used for further study.

\subsection{Antibacterial Agents}

The following antibiotics were used in this study: A novel Antibiotic Adjuvant Entity (AAE) comprising cefepime, amikacin and VRP1020 herein after referred as Potentox obtained from Venus Remedies Limited, Baddi, Himanchal Pradesh, India. The other comparator drugs including ciprofloxacin, levofloxacin, gatifloxacin, ofloxacin, cefepime and amikacin were obtained from Indian market. Potentox was reconstituted in solvent supplied with pack and cefepime was reconstituted with water for injection in accordance with the instructions of manufacturer, rest drugs were in ready to use form and were used as such.

\subsection{DNA Gyrase Extraction}

DNA gyrase from mutant bacterial cells was extracted as previously described Mizuuchi et al. (1984). Briefly, the overnight grown cells in SCDM were collected by centrifugation at $5000 \mathrm{rpm}$ for $5 \mathrm{~min}$ at $25^{\circ} \mathrm{C}$. Approximately $1 \mathrm{~g}$ (wet weight) cells were suspended with $11.2 \mathrm{~mL}$ of Tris-HC1 (0.05 M; pH 7.5) and $2.8 \mathrm{~mL}$ of sucrose $(50 \%)$. Thereafter, $0.5 \mathrm{~mL}$ of a freshly prepared lysozyme $\left(30 \mathrm{mg} \mathrm{mL}^{-1}\right)$ and $2 \mathrm{~mL}$ of SDS $(10 \%)$ were added sequentially and incubated for 1 $\mathrm{h}$ at $37^{\circ} \mathrm{C}$. After incubation, the suspension was centrifuged at $14000 \mathrm{rpm}$ for $15 \mathrm{~min}$ at $25^{\circ} \mathrm{C}$. $10 \mathrm{~mL}$ supernatant was diluted to $13.65 \mathrm{~mL}$ by adding of $1 \mathrm{~mL}$ of Tris-HC1 (0.05 M; pH 7.5), $2 \mathrm{~mL}$ of sucrose $(50 \%)$ and $0.65 \mathrm{~mL}$ of $\mathrm{NaCl}(4 \mathrm{M})$ sequentially. To this 13.65 $\mathrm{mL}$ solution, $1.3 \mathrm{~mL}$ of poly (ethylenimine) (5\%) was added slowly with stirring and stirring was continued for $15 \mathrm{~min}$. After centrifugation at $14000 \mathrm{rpm}$ for $15 \mathrm{~min}$ at $25^{\circ} \mathrm{C}$, pellet was re-suspended in $15 \mathrm{~mL}$ of $\mathrm{NaCl}(0.45$ $\mathrm{M})$, Tris- $\mathrm{HCl}$ (0.05M; pH 7.5), dithiothreitol (1 mM) with a glass rod and stirred for $15 \mathrm{~min}$. The resulting suspension was again centrifuged and pellet was resuspended in $15 \mathrm{~mL}$ of $\mathrm{NaCl}(1 \mathrm{M})$, Tris-HC1 (0.05 M, $\mathrm{pH}$ 7.5), dithiothreitol (1 $\mathrm{mM})$ with a glass rod. Following stirring for $15 \mathrm{~min}$, the suspension was centrifuged and the supernatant was collected into another tube. The supernatant was precipitated by the addition of solid ammonium sulfate $\left(0.4 \mathrm{~g} \mathrm{~mL}^{-1}\right)$ and the precipitate was collected by centrifugation, resuspended in $5 \mathrm{~mL}$ of $\mathrm{KCl}(0.5 \mathrm{M})$, Tris-HC1 $(0.05$ $\mathrm{M}$; pH 7.5), dithiothreitol (1 $\mathrm{mM})$ and was used as DNA gyrase for further study. 


\subsection{Measurement of DNA Gyrase Supercoiling Activity}

DNA gyrase supercoiling activity was measured as described by Morgan-Linnell et al. (2007). The supercoiling activity of DNA gyrase was assayed by the conversion of relaxed pHOT-1 plasmid DNA to the supercoiled form as judge by agarose gel electrophoresis. The assay system consisted of 66.1 $\mu \mathrm{L}$ of $5 \mathrm{X}$ gyrase reaction buffer [(Tris- $\mathrm{HCl}(175 \mathrm{mM}$; $\mathrm{pH}$ 7.5), spermidine (9 $\mathrm{mM})$, bovine serum albumin (34 $\left.\mathrm{mg} \mathrm{mL}^{-1}\right)$ ], $35 \mu \mathrm{L}$ relaxed plasmid DNA $(1 \mu \mathrm{g}$ $\left.\mathrm{mL}^{-1}\right), 3 \mu \mathrm{L}$ ATP $(128 \mathrm{mM})$ and $5.72 \mu \mathrm{L}$ of extracted bacterial DNA gyrase to make final volume of 120 $\mu \mathrm{L}$. The reaction mixture was incubated for $60 \mathrm{~min}$ at $25^{\circ} \mathrm{C}$. Positive and negative controls were also run simultaneously. The reaction mixture of positive control contains $35 \mu \mathrm{L}$ of relaxed plasmid DNA $\left(1 \mu \mathrm{g} \mathrm{mL}{ }^{-1}\right)$, $5.72 \mu \mathrm{L}$ of extracted DNA gyrase of either $P$. aeruginosa PAO strain or mutant, $3 \mu \mathrm{L}$ ATP (128 $\mathrm{mM}), 66.1 \mu \mathrm{L}$ DNA gyrase reaction buffer and 10.2 $\mu \mathrm{L}$ distilled water. The negative control contained only $35 \mu \mathrm{L}$ of relaxed plasmid DNA $\left(1 \mu \mathrm{g} \mathrm{mL} \mathrm{m}^{-1}\right)$. The reaction of both experimental and controls were terminated by adding $2 \mu \mathrm{L}$ of $\operatorname{SDS}(10 \%)$ and $5 \mu \mathrm{L}$ proteinase $\mathrm{K}\left(20 \mathrm{mg} \mathrm{mL} \mathrm{mL}^{-1}\right)$. After termination of reactions, equal volume i.e., $120 \mu \mathrm{L}$ of $24: 1$ chloroform/isoamyl alcohol was added, mixed well and centrifuged at $13,000 \mathrm{Xg}$ for $3 \mathrm{~min}$ at $25^{\circ} \mathrm{C}$ to separate the organic and aqueous phases. An aliquot of $25 \mu \mathrm{L}$ of aqueous phase was separated on $0.8 \%$ agarose gel containing ethidium bromide $\left(1 \mathrm{mg} \mathrm{mL}^{-1}\right)$. The gel was then visualized with gel documentation system (BioRad). After electrophoresis, density of PCR product bands was measured by Image $\mathbf{J}$ software.

\subsection{Minimum Inhibitory Concentration (MIC) Testing}

MICs of drugs were determined by the agar dilution method following the Clinical and Laboratory Standards Institute (CLSI, 2013) guidelines using the bacterial culture equivalent to 0.5 MacFarland. MIC was defined as the lowest concentration of a drug that inhibits the visible growth of a microorganism when incubated at $37^{\circ} \mathrm{C}$ for $18 \mathrm{~h}$. Two fold serial dilutions of drugs were used for the MIC study.

\subsection{Effect of Magnisium Chloride on DNA Gyrase Supercoiling Activity}

To optimize the concentration of $\mathrm{Mg}^{2+}$ for DNA gyrase supercoiling activity, effect of $\mathrm{Mg}^{2+}$ concentrations varing from 15 to $90 \mathrm{mM}$ were evaluated in vitro by keeping total reaction mixture volume $120 \mu \mathrm{L}$ as detailed above.

\subsection{Effect of Disodium Edetate and Sodium Citrate on DNA Gyrase Supercoiling Activity}

To determine whether disodium edetate and sodium citrate might target DNA gyrase, we assessed their effect on DNA gyrase supercoiling activity. For that, a range of concentrations of disodium edtate ( 2 to $12 \mathrm{mM}$ ) and sodium citrate (10 to $140 \mathrm{mM})$ were incorporated into the reaction system as mentioned under DNA gyrase supercoiling activity.

\subsection{Effect of Drugs on DNA Gyrase Supercoiling Activity}

To study the effect of drugs on DNA gyrase supercoiling activity, half of MIC of drugs were used.

\subsection{Statistical Analysis}

Results are expressed as mean \pm SD values. Statistical evaluations were carried out using one way Analysis of Variance (ANOVA) followed by tuke' kramer multiple comparison between control and treatments groups. A value of $* \mathrm{p}<0.05 ; * * \mathrm{p}<0.01 ; * * * \mathrm{p}<0.001$, compared to controls was considered significant.

\section{RESULTS}

\subsection{Strain Identification}

The twelve mutants were confirmed to be of $E$. coli (3), P. aeruginosa (3), A. baumannii (3) and $K$. pneumoniae (3) and were used for further study.

\subsection{MIC Study}

Potentox was the most active against all the selected mutants with MIC values ranging $16-32 \mu \mathrm{g} \mathrm{mL}^{-1}$, where as the MICs for remaining drugs were comparatively higher and for some it even ranged $>512 \mu \mathrm{g} \mathrm{mL}^{-1}$ (Table 1). Half of MICs of the drugs were used in further study as shown in Table 2.

\subsection{Effect of Magnesium on Supercoiling Activity of DNA Gyrase}

The effect of $\mathrm{Mg}^{2+}$ ions on DNA gyrase is shown in Fig. 1. The DNA gyrase showed optimum supercoiling activity at $60 \mathrm{mM} \mathrm{Mg}^{2+}$. The DNA gyrase supercoiling activity was inhibited with further increasing the $\mathrm{Mg}^{2+}$ concentration. 


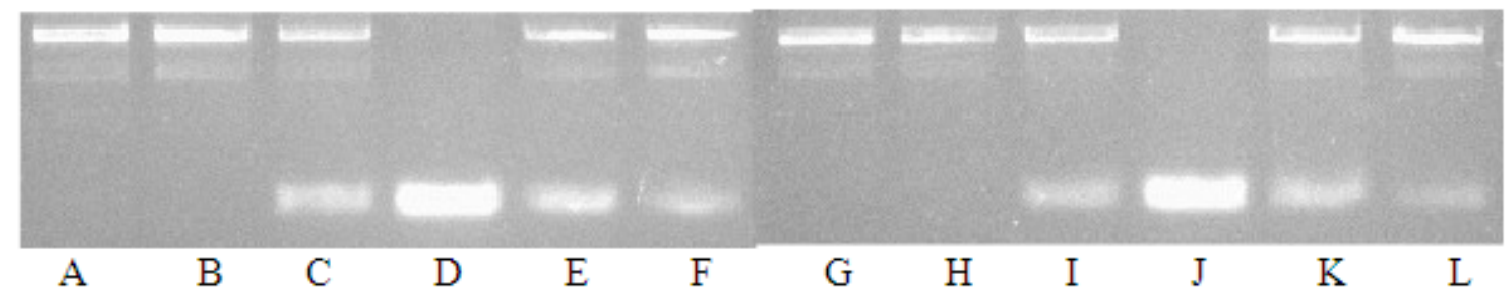

Fig. 1. Effects of $\mathrm{Mg}^{2+}$ on the supercoiling activities of DNA gyrase from $P$. aeruginosa mutant (lane A to $\mathrm{F}$ ) and $P$. aeruginosa PAO1 (lane G to L). A, Relaxed (pHOT-1) DNA; B, $15 \mathrm{mM} \mathrm{Mg}^{2+} ; \mathrm{C}, 30 \mathrm{mM} \mathrm{Mg}{ }^{2+} ; \mathrm{D}, 60 \mathrm{mM} \mathrm{Mg}^{2+} ; \mathrm{E}, 75 \mathrm{mM} \mathrm{Mg}^{2+} ; \mathrm{F}, 90$ $\mathrm{mM} \mathrm{Mg}^{2+}$; G, Relaxed (pHOT-1) DNA; H, $15 \mathrm{mM} \mathrm{Mg}$; I, $30 \mathrm{mM} \mathrm{Mg}^{2+} ; \mathrm{J}^{2} 60 \mathrm{mM} \mathrm{Mg}^{2+} ; \mathrm{K}, 75 \mathrm{mM} \mathrm{Mg}^{2+} ; \mathrm{L}^{2}, 90 \mathrm{mM} \mathrm{Mg}^{2+}$

Table 1. MICs of drugs

\begin{tabular}{|c|c|c|c|c|c|c|c|}
\hline \multirow[b]{2}{*}{ Organisms name } & \multicolumn{7}{|c|}{ Drugs $[\mathrm{MIC}(\mu \mathrm{g} / \mathrm{mL})]$} \\
\hline & Gatifloxacin & Ciprofloxacin & Ofloxacin & Levofloxacin & Cefepime & Amikacin & Potentox \\
\hline K. pneumoniae & $32-64$ & $256-512$ & $64-128$ & $>512$ & $>512$ & $128-512$ & $16-32$ \\
\hline A. baumannii & $16-32$ & $32-128$ & $64-128$ & $256-512$ & $>512$ & $128-512$ & $16-32$ \\
\hline P. aeruginosa & $16-32$ & $64-128$ & $32-128$ & $>512$ & 256 & 128 & $16-32$ \\
\hline E. coli & $16-32$ & $256-512$ & $64-128$ & $256-512$ & $>512$ & 256 & $16-32$ \\
\hline P. aeruginosa PAO MTCC 3541 & 32 & 32 & 64 & 32 & 16 & 8 & 4 \\
\hline
\end{tabular}

Table 2. Concentration of drugs used for the study

\begin{tabular}{|c|c|c|c|c|c|c|c|}
\hline \multirow[b]{2}{*}{ Organisms name } & \multicolumn{7}{|c|}{ Drugs [half MIC $(\mu \mathrm{g} / \mathrm{mL})]$} \\
\hline & Gatifloxacin & Ciprofloxacin & Ofloxacin & Levofloxacin & Cefepime & Amikacin & Potentox \\
\hline K. pneumoniae & 16 & 128 & 64 & 512 & 512 & 128 & 8 \\
\hline A. baumannii & 8 & 64 & 64 & 128 & 512 & 128 & 8 \\
\hline P. aeruginosa & 8 & 64 & 64 & 512 & 128 & 64 & 8 \\
\hline E. coli & 8 & 128 & 32 & 256 & 512 & 128 & 8 \\
\hline P. aeruginosa PAO MTCC 3541 & 16 & 16 & 32 & 16 & 8 & 4 & 2 \\
\hline
\end{tabular}

The study was conducted using all the mutants strains of E. coli, P. aeruginosa, A. baumannii and $K$. pneumoniae and similar trends of results were obtained, therefore here we have presented the results of only $P$. aeruginosa mutants.

\subsection{Effect of Disodium Edetate and Sodium Citrate on Supercoiling Activity of DNA Gyrase}

The inhibitory effect of disodium edetate on supercoiling activity of DNA gyrase is depicted in Fig. 2: Lane A is relaxed pHOT-1 DNA and lane B is relaxed plasmid converted into supercoiled in the presence of DNA gyrase. Lane $\mathrm{C}$ to $\mathrm{H}$ are various concentrations of disodium edetate. From the picture it is apparent that disodium edtate inhibits DNA gyrase activity. The significance inhibition starts from $4 \mathrm{mM}$ $(p<0.05)$. The effect of various concentrations of sodium citrate on DNA gyrase activity was studied in 10 to $140 \mathrm{mM}$ concentrations. Sodium citrate inhibited the DNA gyrase activity at $50 \mathrm{mM}$ and above (data not shown). Further, quantitative measurement of the supercoiled DNA peak by a densitometric assay was carried out and results are presented in Fig. 3. DNA gyrase inhibition was observed with low concentrations of disodium edetate and 50 and $100 \%$ inhibition on DNA gyrase activity was noted at approximately 4.2 and $10 \mathrm{mM}$ disodium edetate. On the other hand, 50 and $100 \%$ inhibition of DNA gyrase was found at 65 and $140 \mathrm{mM}$ sodium citrate.

\subsection{Effect of Drugs on Supercoiling Activity of DNA Gyrase}

The results of effect of different drugs on DNA gyrase supercoiling activity is shown in Fig. 4. Results revealed Potentox inhibits the supercoiling activity of DNA gyrase at half of MIC of drug. On the other hand, other comparator drugs except gatifloxacin did not inhibit significantly the supercoiling activity of mutants as well as positive control. 


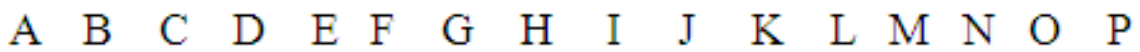

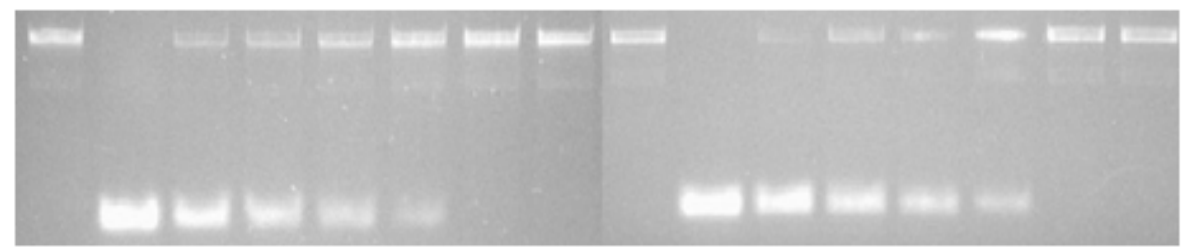

Fig. 2. Inhibitory effects of disodium edetate on the supercoiling activities of DNA gyrase from $P$. aeruginosa mutant (lanes A to H) and $P$. aeruginosa PAO1 (lanes I to P). A, Relaxed (pHOT-1) DNA; B, Relaxed plasmid converted into supercoiled in the presence of DNA gyrase; C, $2.0 \mathrm{mM}$ disodium edetate; D, $4.0 \mathrm{mM}$ disodium edetate; $\mathrm{E}, 6.0 \mathrm{mM}$ disodium edetate; F, $8.0 \mathrm{mM}$ disodium edetate; G, $10.0 \mathrm{mM}$; disodium edetate; H, $12.0 \mathrm{mM}$ disodium edetate' I, Relaxed (pHOT-1) DNA; J, Relaxed plasmid converted into supercoiled in the presence of DNA gyrase; K, $2.0 \mathrm{mM}$ disodium edetate; $\mathrm{L}, 4.0 \mathrm{mM}$ disodium edetate; M, 6.0 $\mathrm{mM}$ disodium edetate; $\mathrm{N}, 8.0 \mathrm{mM}$ disodium edetate; $\mathrm{O}, 10.0 \mathrm{mM}$; disodium edetate; $\mathrm{P}, 12.0 \mathrm{mM}$ disodium edetate

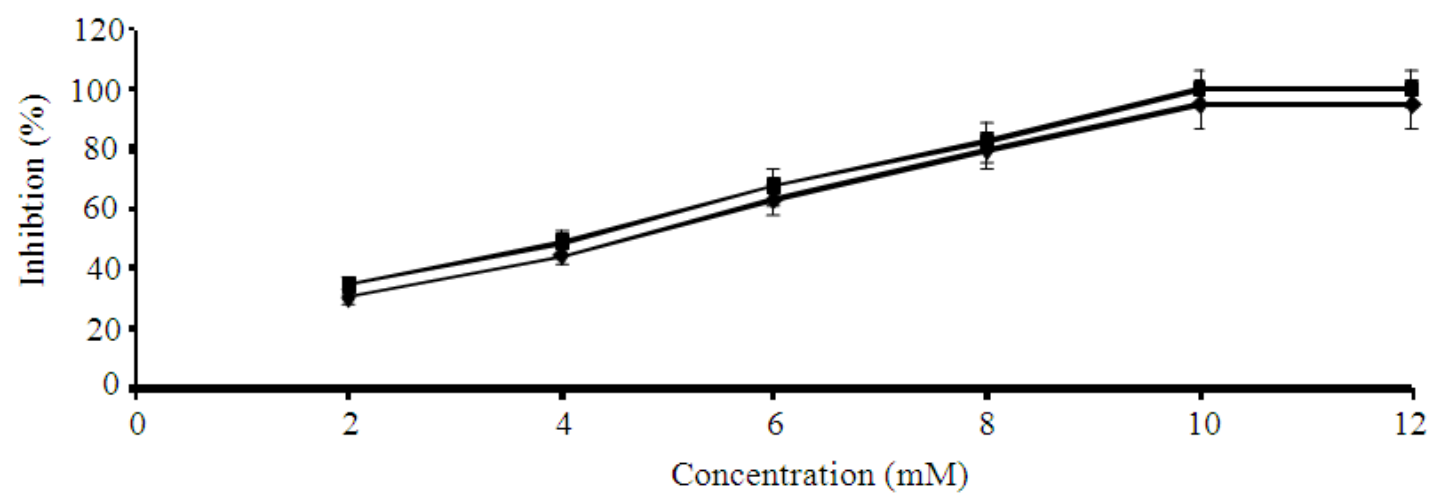

Fig. 3. Inhibitory patterns of disodium edetate on the supercoiling activities of DNA gyrase from $P$. aeruginosa mutant and $P$. aeruginosa PAO1

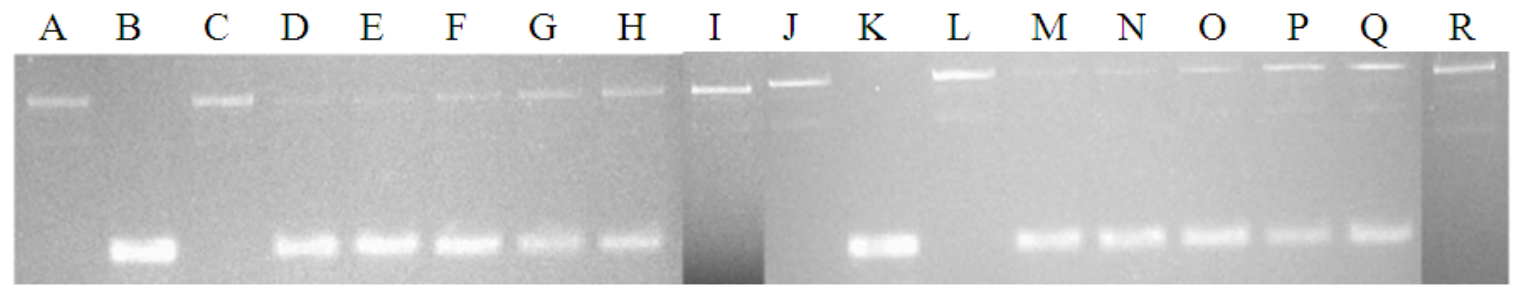

Fig. 4. Inhibitory effect of drugs on supercoiling activities of DNA gyrase from $P$. aeruginosa mutant (lane A to I ) and $P$. aeruginosa PAO1 (lane J to R). A, Relxed (pHOT-1) DNA; B, Relaxed plasmid converted into supercoiled in the presence of DNA gyrase; C, Potentox; D, ciprofloxacin; E, ofloxacin; F, cefepime; G, levofloxacin; H, amikacin' I, gattifloxacin; J, Relxed (pHOT-1) DNA; K, Relaxed plasmid converted into supercoiled in the presence of DNA gyrase; L, Potentox; M, ciprofloxacin; N, ofloxacin; O, cefepime; P, levofloxacin; Q, amikacin; R, gattifloxacin

Quantitative measurement of the supercoiled DNA peak by a densitometer was also performed, inhibitory patterns of drugs against the supercoiling activity is shown in Fig. 5. Potentox and gatifloxacin inhibited DNA gyrase and supercoiling at lower concentration and were the most effective. DNA gyrase from mutants was highly resistant to quinolones and sensitive to Potentox. The 50\% inhibitory doses of these drugs against the supercoiling are shown in Table 3. 


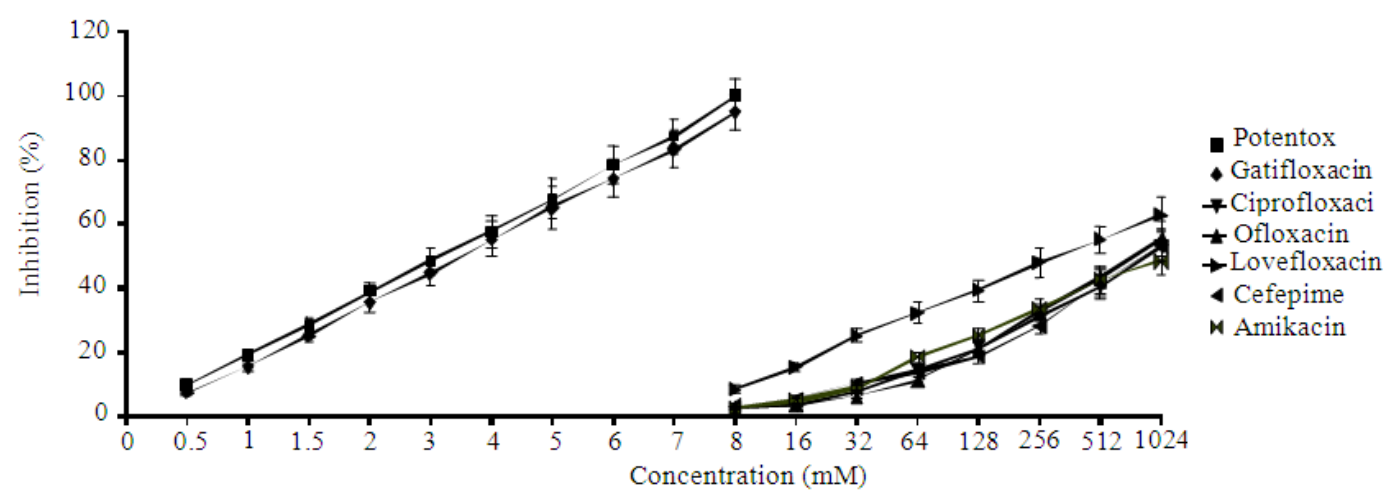

Fig. 5. Inhibitory doses of drugs on the supercoiling activity of DNA gyrase

Table 3. Inhibitory doses of drugs on the supercoiling activity of DNA gyrase

\begin{tabular}{lcc}
\hline & $\mathrm{ID}_{50}(\mu \mathrm{g} / \mathrm{mL})$ & \\
\cline { 2 - 3 } Name of drugs & P. aeruginosa mutant & P. aeruginosa PAO1 \\
\hline Potentox & 3.08 & 3.03 \\
Gatifloxacin & 3.07 & 3.01 \\
Ciprofloxacin & 964.00 & 954.00 \\
Ofloxacin & 937.00 & 929.00 \\
Levofloxacin & 811.00 & 805.00 \\
Cefepime & 957.00 & 943.00 \\
Amikacin & 992.00 & 981.00 \\
\hline
\end{tabular}

\section{DISCUSSION}

The prevalence of fluoroquinolone resistance among Enterobacteriaceae has imposed a major threats to clinicians in treating serious multi-drug resistant gram negative infections due to the lack of suitable effective drugs. DNA gyrase is an essential bacterial enzyme which is particularly involved in the ATP-dependent negative supercoiling of DNA. DNA gyrase has been shown to be good target for antibiotics, including the quinolones. DNA supercoiling reaction requires, in addition to ATP, divalent metal ions specially $\mathrm{Mg}^{2+}$ which is required for ATP hydrolysis (Sengupta et al., 2011). Our results also showed that DNA gyrase exhibited optimum supercoiling activity at $60 \mathrm{mM} \mathrm{Mg}^{2+}$.

The gyrase induced reaction has been used as a measure of the efficiency of a particular drug as gyrase inhibitor (Collin et al., 2011). Our results clearly demonstrate that non antibiotic adjuvants, disodium edetate and sodium citrate inhibited the DNA gyrase thus inhibition of DNA supercoiling activity. However, disodium edetate was 4 to 6 times more effective than sodium citrate.
We observed that novel antibiotic adjuvant entity Potentox (cefepime plus amikacin with VRP1020) was more active against quinolone resistant organisms. We observed that all the DNA gyrase mutants of E. coli, A. baumannii, P. aeruginosa and $K$. pneumoniae were susceptible to Potentox. Non antibiotic adjuvant disodium edtate chelates the magnesium ions and stops ATP hydrolysis resulting in the inactivation of mutant DNA Gyrase and hence overcoming resistance. Previously, it has been demonstrated disodium edtate diminished the barrier of drug penetration (Jeong et al., 2005), inhibited efflux pump in E. coli and P. aeruginosa (Chaudhary et al., 2012; Chaudhary and Payasi, 2012).

Our results demonstrated that the addition of Potentox at the concentration of half of MIC into the reaction system having DNA gyrase, relaxed closedcircular DNA and $\mathrm{Mg}^{2+}$ led to complete inhibition of DNA gyrase supercoiling activities. The exact mechanism of inhibition of DNA gyrase by Potentox is not known. However, it has been proposed that probably this novel antibiotic adjuvant entity helps in the formation of complex by increasing the affinity which leads inhibition of DNA gyrase. Similarly, gattifloxacin also inhibited the DNA gyrase supercoiling activities, but the drug is banned for sale in India due to its toxic effects. However, other comparator drugs failed to prevent the inhibition of DNA gyrase supercoiling activities.

It has been reported that ciprofloxacin resistance correlates with decreased affinity of the drug with the DNA gyrase enzyme (Minarini and Darini, 2012). Furthermore, ID50 values of Potentox and gatifloxacin against DNA gyrase were less when compared with their MICs suggesting the both of these drugs were effective in less quantity to inhibit DNA gyrase leading killing of 
bacteria. However, gatifloxacin is banned in India for systemic use (Central Drugs Standard Control Organization, Dte. GHS, Ministry of Health and Family Welfare, Government of India. Retrieved 2013-9-17).

\section{CONCLUSION}

Disodium edetate, a non antibiotic adjuvant efficiently inhibits the supercoiling activity of DNA gyrase. If this adjuvant was used together with drugs synergistically the combination can again inhibit supercoiling activity mediated by DNA gyrase. It can be concluded that Potentox is an effective solution for the treatment of infections caused by fluoroquinolone resistant organism having DNA gyrase mutation.

\section{ACKNOWLEDGEMENT}

Researchers are thankful to sponsor, Venus Medicine Research Centre, Germany for providing assistance to carry out this study. Also thanks to institute which provided strains. We also thank Dr. N.D Chaurasiya (National Centre for Natural Products Research, School of Pharmacy, University of Mississippi, USA) for providing strains.

\section{REFERENCES}

Chaudhary, M. and A. Payasi, 2012. Ethylenediaminetetraacetic acid: A non antibiotic adjuvant enhancing Pseudomonas aeruginosa susceptibility. Afr. J. Microbiol. Res., 6: 6799-6804. DOI: $10.5897 / A J M R 12.1407$

Chaudhary, M., S. Kumar and A. Payasi, 2012. A novel approach to combat acquired multiple resistance in Escherichia coli by using EDTA as efflux pump inhibitor. J. Microb. Biochem. Technol., 4: 126-130. DOI: 10.4172/1948-5948.1000082

Chenia, H.Y., B. Pillayl and D. Pillay, 2006. Analysis of the mechanisms of fluoroquinolone resistance in urinary tract pathogens. J. Antimicrob. Chemother., 58: 1274-1278. DOI: 10.1093/jac/dkl404

CLSI, 2013. Performance standards for antimicrobial susceptibility testing; twenty-first informational supplement. Clinical and Laboratory Standards Institute. Wayne, PA.

Collin, F., S. Karkare and A. Maxwell, 2011. Exploiting bacterial DNA gyrase as a drug target: Current state and perspectives. Applied Microbiol. Biotechnol., 92: 479-497. PMID: 21904817
Coyne, S., P. Courvalin and B. Perichon, 2011. Effluxmediated antibiotic resistance in acinetobacter spp. Antimicrob. Agents Chemother., 55: 947-953. PMID: 21173183

Gruger, T., J.L. Nitiss, A. Maxwell, E.L. Zechiedrich and P. Heisig et al., 2004. A mutation in Escherichia coli DNA gyrase conferring quinolone resistance results in sensitivity to drugs targeting eukaryotic topoisomerase II. Antimicrob. Agents Chemother., 48: 4495-4504. PMID: 15561817

Hawkey, P.M., 2003. Mechanisms of quinolone action and microbial response. J. Antimicrob. Chemother., 1: 29-35. PMID: 12702701

Jacoby, G.A., K.E. Walsh, D.M. Mills, V.J. Walker and H. Oh et al., 2006. qnrB another plasmid-mediated gene for quinolone resistance. Antimicrob. Agents Chemother., 50: 1178-1182. PMID: 16569827

Jeong, J.Y., H.J. Yoon, E.S. Kim, Y. Lee and S.H. Choi et al., 2005. Detection of $q n r$ in clinical isolates of Escherichia coli from Korea. Antimicrob. Agents Chemother., 49: 2522-2524. DOI: 10.1128/AAC.49.6.2522-2524.2005

Khan, F., M. Rizvi, I. Shukla and A. Malik, 2011. A novel approach for identification of members of Enterobacteriaceae isolated from clinical samples. Biol. Med., 3: 313-319.

Minarini, L.A.R. and A.L.C. Darini, 2012. Mutations in the quinolone resistance-determining regions of gyrA and parC in Enterobacteriaceae isolates from Brazil. Braz. J. Microbiol., 43: 1309-1314. DOI: 10.1590/S1517-83822012000400010

Mizuuchi, K., M. Michiyo, M.H. Oes and M. Gellert, 1984. Cloning and simplified purification of Escherichia coli DNA gyrase A and B proteins. J. Biol. Chem., 259: 9199-9201.

Morgan-Linnell, S.K., H. Hiasa, L. Zechiedrich and J.L. Nitiss, 2007. Assessing sensitivity to antibacterial topoisomerase II inhibitors. Curr. Protoc. Pharmacol. DOI: 10.1002/0471141755

Morgan-Linnell, S.K., L.B. Boyd, D. Steffen and L. Zechiedrich, 2009. Mechanisms accounting for fluoroquinolone resistance in Escherichia coli mutants. Antimicrob. Agents Chemother., 53: 235241. PMID: 18838592

Ruiz, J., 2003. Mechanisms of resistance to quinolones: target alterations, decreased accumulation and DNA gyrase protection. J. Antimicrob. Chemother., 51: 11097-11017. PMID: 12697644 
Sato, T., S.I. Yokata, I. Uchida, T. Okubu and K. Ishihara et al., 2011. A Fluoroquinolone-resistant Escherichia coli clinical isolate without quinolone resistance-determining region mutations found in Japan. Antimicrob. Agents Chemother., 55: 39643965. DOI: 10.1128/AAC.00532-11

Sengupta, S., A. Ganguly, A. Roy, S.B. Dasgupta and I. D'Annessa et al., 2011. ATP independent type IB topoisomerase of Leishmania donovani is stimulated by ATP: An insight into the functional mechanism. Nucl. Acids Res., 39: 3295-309. DOI: 10.1093/nar/gkq1284, PMID: 21186185
Strahilevitz, J., G.A. Jacoby, D.C. Hooper and A. Robicsek, 2009. Plasmid-mediated quinolone resistance: A multifaceted threat. Clin. Microb. Rev., 22: 664-689. PMID: 19822894

Tretter, E.M. and J.M. Berger, 2012. Mechanisms for defining supercoiling set point of DNA gyrase orthologs. J. Biol. Chem., 287: 18645-18654. DOI: 10.1074/jbc.M112.345736 